Digitalizacja archiwalnych numerów czasopisma naukowego Analecta Cracoviensia 1-24 (1969-1992)

i ich publikacja w otwartym dostępie - zadanie finansowane w ramach umowy 672/P-DUN/2017 ze środków

Ministra Nauki i Szkolnictwa Wyższego przeznaczonych na działalność upowszechniającą naukę

KS, ROMAN ROŻDŻENSSKI

\title{
Z POZNAWCZEJ PROBLEMATYKI SUBSTANCJI
}

Stosunek do metafizyki wydaje się być tym, co zasadniczo odróżnia myślenie filozoficzne w średniowieczu oraz w czasach nowożytnych. Powiada się, że średniowiecze było okresem panowania metafizyki, natomiast czasy nowożytne cechuje zdecydowana opozycja wobec niej. Istota zaś tej opozycji wiąże się ze stawianiem pytań o poznawczą wartość metafizycznych pojęć i twierdzeń. Myślenie nowożytne czyniło kolejno przedmiotem swojego krytycznego namysłu poszczególne kluczowe pojęcia tradycyjnej metafizyki. Celem tegoż krytycznego namysłu było sprawdzenie, czy owe zasadnicze pojęcia metafizyki odpowiadaja rzeczywistości, tj. czy pochodzą one z doświadczenia. Nowożytne myślenie cechuje bowiem przekonanie, iż tylko pozytywne wykazanie czegoś takiego pozwoliłoby uznać metafizykę za dziedzinę autentycznej wiedzy o rzeczywistości.

Początki nowożytnego krytycznego namysłu nad podstawowymi pojęciami tradycyjnej metafizyki wiąże się z dociekaniami trzech brytyjskich empirystów: Locke'a. Berkley'a i Hume'a. Wynik ich namysłu był jak wiadomo - negatywny. Zapoczątkowało to proces tzw. destrukcji metafizyki w myśleniu nowożytnym.

Jednym z najbardziej podstawowych pojęć tradycyjnej metafizyki było pojęcie substancji, czyli podłoża spostrzegalnych zmysłowo cech (akcydensów). Poznawcza wartość tego pojęcia nie ulegała wątpliwości - tak dla Arystotelesa, jak i dla późniejszych myślicieli scholastycznych. A nawet jeszcze obecnie, szczególnie w nurcie filozofii tzw. neo-tomistycznej, nadal uznaje się poznawczy charakter tego pojęcia, pomimo że było ono w czasach nowożytnych przedmiotem wielorakiej krytyki.

To wielowiekowe panowanie pojęcia substancji w europejskim myśleniu filozoficznym jest pewnym faktem. Fakt ten prowadzi nas obecnie do postawienia pytania: dlaczego tak długo i tak powszechnie pojęcie to było uznawane w filozofii za odpowiadające (w sposób oczywisty) temu, co fundamentalne w rzeczywistości?

Jest to - jak widać - pytanie o rację przekonania o poznawczym charakterze pojẹcia substancji. Otóż, poszukiwanie tej racji stanowić będzie intencję przewodnią rozważań zawartych w niniejszym artykule. 
Odpowiednio do tej intencji przewodniej zostanie najpierw zarysowane arystotelesowskie rozumienie pojęcia substancji. Następnie będzie przedstawiona ( $\mathrm{w}$ istotnym zarysie) krytyka zasadności tego pojęcia, podjęta niegdyś przez Johna Locke'a. Z kolei ta Locke'owska krytyka tradycyjnego pojęcia substancji stanie się przedmiotem naszego krytycznego namysłu. W tym zaś krytycznym badaniu chodzić będzie o to, czy jego (tzn. Locke'owska) empirystyczna krytyka tradycyjnego pojęcia substancji sama powinna być uznana za trafną.

ROZUMIENIE POJECIA SUBSTANCJI W ARYSTOTELESOWSKIEJ METAFIZYCE

Powszechnie przyjmuje się, iż koncepcja substancji była dziełem Arystotelesa. Dojrzewała ona w jego myśleniu w trakcie dyskusji ze stanowiskiem Platona, szczególnie gdy idzie o sprawę przedmiotu naukowego poznania ${ }^{1}$. Arystotelesowska intuicja substancji jako podstawowego przejawu bytowego okazała się niezwykle trwała dla myślenia filozoficznego w wiekach średnich. Można powiedzieć, że dalsze dzieje koncepcji substancji okazały się tylko najrozmaitszymi modyfikacjami myśli Stagiryty ${ }^{2}$.

Zdaniem Arystotelesa o bycie można mówić w różnych znaczeniach, gdyż jest on mnogi i posiada swoje najrozmaitsze przejawy czy też postacie $^{8}$. Odpowiadają im pewne podstawowe grupy orzeczników, czyli tzw. „kategorie”. Arystoteles wyliczył dziesięć takich podstawowych kategorii bytowania, wśród których wyjątkowe znaczenie przypisywał kategorii substancji. Powodem tego była okoliczność, iż tylko substancja jest tym, co bytowo samodzielne, tzn. tym, co istnieje ,w sobie”, a nie w czymś innym i dlatego stanowi podstawę (warunek możliwości) istnienia wszelkich innych przejawów bytowych jako przejawów bytowo niesamodzielnych ${ }^{4}$.

W swojej Metafizyce Arystoteles wskazywał, że wyraz „substancja" posiada - co najmniej - cztery znaczenia. Przez substancję rozumie się mianowicie albo „istotę” czegoś, albo „ogól” (czyli tzw. powszechnik), albo „rodzaj”, albo też wreszcie „substrat”, czyli podłoże własności ${ }^{5}$. Odnośnie do tego ostatniego znaczenia wyrazu ,,substancja” dodawał: „Substrat jest to coś, o czym wszystkie inne predykaty są orzekane, podczas gdy on sam nie może już być orzekany o niczym" ". Dlatego dla Arystotelesa bytem była przede wszystkim substancja, pojęta jako

${ }^{1}$ M. A. Kr ą piec, Metafizyka, Poznań 1966, 304.

2 Por. tamże, 305.

3 Arystoteles, Metafizyka, tłum. K. Leśniak, Warszawa 1984, 158.

- M. A. Krąpiec, jw., 305-306.

5 Arystoteles, jw., 161.

- Por. tamże, 161. 
„substrat", czyli jako podłoże wszelkich innych przejawów bytowych. Wszak bez niej cała rzeczywistość byłaby w ogóle niezrozumiała ${ }^{7}$. Te wszelkie inne przejawy bytowe, które jako bytowo niesamodzielne istnieją jedynie na podłożu określonej substancji, określano mianem ,pprzypadłości” czy też „,akcydensów”.

Arystotelesowska koncepcja substancji została później całkowicie zaakceptowana m.in. przez św. Tomasza z Akwinu. On również uznał, że być bytem $\mathrm{w}$ znaczeniu podstawowym to oznacza być substancją, czyli postacią bytu zdolną do samoistnienia. Tę samodzielność bytową uznał św. Tomasz za sposób bytowania charakterystyczny tylko dla substancjalnych przejawów bytowych ${ }^{8}$.

Tomaszowa akceptacja arystotelesowskiej koncepcji substancji nie była wówczas czymś wyjątkowym. Wszak myśl Arystotelesa wywierała już wówczas istotny wpływ na myślicieli scholastycznych. Jednakże już u schyłku średniowiecza pojawia się pogląd, który jest zapowiedzią przyszłego nowożytnego ataku na tradycyjne pojęcia metafizyczne: ataku ze stanowiska empiryzmu. Pogląd ten był dziełem Wilhelma Ockhama, czternastowiecznego myśliciela angielskiego, związanego ze środowiskiem intelektualnym Oxfordu ${ }^{9}$. Głosił on, że nie dostrzegamy istnienia substancji jako niezależnej od spostrzeganych przez nas przypadłości. Dlatego uważał, iż należy ideę substancji uznać za coś tylko subiektywnego. Rzeczywisty byt jest jedynie zespołem przypadłości i dlatego podstawowe znaczenie $\mathrm{w}$ badaniu wszelkiego rzeczywistego bytu posiada eksperyment.

Jak to niebawem zobaczymy, pogląd ten był bliski stanowisku J. Locke'a, który uważał, że substancja nie jest nam nigdy dana w jakimkolwiek doświadczeniu.

\section{LOCKE'A KRYTYKA POJECIA SUBSTANCJI}

Przede wszystkim należy podkreślić, iż sam Locke uznawał jako fakt istnienie powszechnego wśród ludzi przeświadczenia o realności substancji. Wychodząc od tego faktu starał się krytycznie przebadać, na ile to powszechne przekonanie należałoby uznać za uzasadnione. Otóż - jego zdaniem - byłoby to przekonanie tylko wówczas uzasadnione, gdyby dało się wykazać, iż pojęcie substancji pochodzi $\mathrm{z}$ doświadczenia, tj. posiada rzeczywiste oparcie $w$ danych odpowiedniego doświadczenia. Gdyż — jak podkreślał — „w umyśle cały materiał dla rozumu i wiedzy

7 M. A. Kr ąp ie c, jw., 307.

8 Por. tamże, 312.

- Por. tamże, 314.

10 - Analecta Cracoviensia 
bierze się z doświadczenia" ${ }^{10}$. Na wszelkie zaś doświadczenie składaja się - zdaniem Locke'a - dwojakiego rodzaju obserwacje:

a) nasze obserwacje zwrócone ku zmysłowym rzeczom zewnętrznym,

b) nasze obserwacje skierowane ku wewnętrznym czynnościom duchowym, które spostrzegamy i które są przedmiotem naszej refleksji ${ }^{11}$.

W rozważaniach swoich nie stosuje Locke wyrażenia ,pojęcie substancji", lecz mówi o ,idei substancji”. Idzie mu jednak ostatecznie o to samo. Wskazuje bowiem, że przez „ideę” rozumie wszelką rzecz, która jest przedmiotem myśli, czyli np. obraz fantazji, pojęcie, gatunek, wszystko to, czym umysł może się zajmować gdy myśli ${ }^{12}$. A zatem zakres „idei” czegoś jest u Locke'a szerszy niż zakres pojęcia czegoś i obejmuje sobą zakres pojęcia. W przypadku substancji zakres ,idei substancji" pokrywa się zasadniczo z zakresem pojęcia substancji. Dlatego, jak się wydaje, referując poglądy Locke'a możemy tych wyrażeń używać zamiennie.

Jest faktem - wskazywał Locke - że posiadamy liczne i wielorakie idee. Wszystkie one pochodzą ze wspomnianych wyżej dwôch źródeł, tzn. bądź to $z$ obserwacji zewnętrznych (względem nas) przedmiotów, bądź téz $z$ wewnętrznego spostrzegania naszych czynności i stanów duchowych. Dlatego rozum - dodawał - zdaje się nie posiadać najsłabszego bodaj przebłysku jakiejkolwiek idei, która by nie pochodziła z doświadczenia ${ }^{13}$. Gdy przeto postaramy się o uważne przebadanie idei, które posiada nasz umysł, wówczas - stwierdzał Locke - przekonujemy się, że żadnej idei substancji nie posiadamy, oraz że nie możemy jej zdobyć ani na drodze zmysłowego spostrzegania rzeczy zewnętrznych, ani też na drodze refleksji ${ }^{14}$. Cóż bowiem - zapytywał znaczy dla nas faktycznie słowo ,substancja”? Wszak z wyrazem tym nie wiąże siẹ dla nas żaden określony sens, lecz jedynie jakieś nieokreślone mniemanie, dotyczące nie wiedzieć czego, o czym nie posiadamy żadnej pozytywnej idei. To nieokreślone coś traktujemy jako ,substrat”, czyli podłoże znanych nam idei, np. idei kształtu, barwy, ciężaru, itp. ${ }^{15}$

Dlaczego jednak taka dziwna hipostaza pojawia się w naszych umysłach przy okazji np. zmysłowego oglądania czegoś? Otôż - wskazywał Locke - przy obserwacji czegoś dana nam jest zazwyczaj pewna liczba idei prostych (np. idei barwy, kształtu itp.) jako idei współwystę-

$10 \mathrm{~J}$. Locke, Rozważania dotyczace rozumu ludzkiego, t. 1, tłum. B. Gawe c k i, Kraków 1955, 120.

11 Por. tamże, 120.

12 Por. tamże, 146.

13 Por. tamże, 121.

14 Por. tamże, 106.

15 Por. tamże, 107. 
pujących ze sobą. I tylko dlatego, że nie jesteśmy w stanie uprzytomnić sobie $\mathrm{w}$ jaki sposób owe proste idee mogłyby samodzielnie bytować (czy też jedna $\mathrm{z}$ drugiej), uciekamy się do przypuszczenia, że wszystkie one istnieją na jakimś wspólnym podłożu, które je bytowo podtrzymuje. To zaś podłoże zwykliśmy nazywać właśnie „substancją" ${ }^{16}$. Siłą myślowego nawyku uznajemy istnienie owego podłoża, pomimo tego, iż brak nam jakiejkolwiek wyraźnej i jasnej idei, na czym by owo podłoże miało konkretnie polegać ${ }^{17}$.

Idea (resp. pojęcie) substancji nie pochodzi zatem $\mathrm{z}$ doświadczenia. Dlatego też nie wyraża ona jakiejkolwiek rzetelnej wiedzy o rzeczywistości. Potoczny fakt, że posiadamy takie słowo oraz, że wiążemy z nim pewne niejasne mniemanie, niczego tutaj nie jest $w$ stanie zmienić. Posiadanie przez nas tego słowa i związanych z nim mniemań wyraża tylko pewien nasz myślowy nawyk, nie zaś jakieś nasze określone poznanie. Jest to nawyk wiązania ze sobą rozmaitych ,idei prostych" i następnie traktowania uzyskanych w ten sposób złożeń (,idei złożonych”) jako prostych idei pochodzących z doświadczenia.

Z doświadczenia pochodzą - podkreślał Locke - tylko nasze proste idee, takie np. jak idee kształtu, barwy, ciężaru, itp. Dlatego nic nie wiemy - i nic nie możemy $w$ ogóle wiedzieć — poza granicami naszych idei prostych ${ }^{18}$. Jest to nieprzekraczalna granica wszelkiej naszej rzetelnej wiedzy. Idea substancji nie jest owocem naszego rzetelnego poznania rzeczywistości, lecz jest ona jedynie wyrazem naszych bezpodstawnych mniemań na temat rzeczywistości.

\section{PYTANIE O GENEZE ARYSTOTELESOWEGO POJMOWANIA SUBSTANCJI}

Jest rzeczą oczywistą, iż wypracowane przez Arystotelesa pojęcie substancji nie może pochodzić z takiego - empirystycznie rozumianego doświadczenia, o jakim mówił Locke. Nic w tym dziwnego. Wszak tego rodzaju koncepcja doświadczenia nie była jeszcze znana w czasach Arystotelesa. Nie oznacza to jednak, że Arystotelesowe pojmowanie substancji nie posiadało w ogóle żadnego oparcia w danych odpowiedniego doświadczenia. Istnieje bowiem takie doświadczenie - i to o charakterze nieempirystycznym - którego faktycznie ustawicznie dokonujemy w toku naszej codziennej aktywności, żyjąc po prostu. Mam tu na myśli przede wszystkim nasze tzw. potoczne doświadczenie zewnętrznych wzg̣lędem nas rzeczy zmysłowych. Takiego potocznego doświadczania rzeczy doko-

\footnotetext{
16 Por. tamże, 408.

17 Por. tamże, 410.

18 Por. tamże, 437.
} 
nujemy bezwiednie a ustawicznie w trakcie naszego potocznego życia, nie tylko przed wszelką teorią na temat tego, czym jest doświadczenie, ale nawet przed wszelką refleksją uprzytamniającą nam fakt, że oto właśnie coś doświadczamy.

A zatem Arystoteles, chociaż nie znał nowożytnej empirystycznej koncepcji doświadczenia, to przecież faktycznie dysponował potocznym doświadczeniem rzeczy zmysłowych, którego dokonuje ustawicznie na co dzień każdy człowiek. Doświadczenie to posiada charakter bezpośredniego kontaktu (poznawczego) z rzeczywistością, tzn. kontaktu niezapośredniczonego przez żadne aprioryczne teorie i spekulacje na temat istoty wszelkiego doświadczenia. Nie dokonuje się ono według określonego i z góry już jakoś założonego wzorca doświadczenia, lecz przebiega samorzutnie jako faktycznie oto dokonujące się doświadczanie czegoś przez kogoś. Wynikiem takiego bezpośredniego kontaktu poznawczego są określone, tzw. potoczne intuicje na temat doświadczanej przez nas w ten sposób rzeczywistości

Ogół tych potocznych intuicji składa się na pewną naszą postawę wobec rzeczywistości. Postawa ta kształtuje się w nas w toku codziennej aktywności (życiowej) w sposób samorzutny i bezwiedny, tzn. przed wszelką refleksją. Z tego właśnie względu postawa ta może być określana jako postawa spontanicznego, tzw. naiwnego realizmu. Naiwność tej postawy oznacza po prostu, iż cechuje ją całkowity brak teoretycznego samozarozumienia własnej genezy; nie oznacza natomiast negatywnej oceny jej poznawczej wartości. Wszak zawsze można podjąć trud rozświetlenia poznawczej genezy tej postawy naiwnego realizmu. Zaś takie rozświetlenie winno się dokonywać poprzez skrupulatną analizę przebiegu naszego faktycznego (tj. potocznego) doświadczania rzeczy otaczającego nas świata. Jesteśmy dziećmi naszego czasu, czasu nowożytnego krytycyzmu. Ten zaś nowożytny krytycyzm, napiętnowany tendencją empirystyczną, uczynił nas jakby ślepymi na nasze spontaniczne, bezpośrednie doświadczanie rzeczywistości, na którą codziennie napotykamy jako na obecną w zasiegu ręki. Empirystyczny krytycyzm wmówił nam, że tylko wtedy naprawdę czegoś poznawczo doświadczamy, gdy doświadczanie to przebiega według określonych, z góry już jakoś wyznaczonych reguł, tzn. według pewnego metodologicznego a priori. Tylko takie doświadczenie uznaje on za rzetelne, godne zaufania.

Empirystyczna koncepcja doświadczenia zdaje się przeto opierać na swoistym metodologicznym a priori. Aprioryzm ten polega na tym, że przed wszelkim zbadaniem reguł, według których przebiega nasze faktyczne, spontaniczne doświadczenie np. rzeczy zmysłowych, z góry rozstrzyga się o tym, jak musi przebiegać wszelkie doświadczenie, aby mogło być uznane za posiadające rzeczywistą wartość poznawczą. 
Aprioryzm ten przynależy istotowo do myślenia empirystycznego, które w znaczącym stopniu kształtuje ducha naszej epoki. Dlatego myślenie to jest zawsze - w określonym stopniu - naszym własnym udziałem. Tłumi ono w nas skutecznie wrażliwość na dane naszego spontanicznego, bezpośredniego doświadczenia świata. Czyż nie dlatego z takim zazwyczaj lekceważeniem odnosimy się do danych naszego tzw. potocznego doświadczenia i do naszych potocznych intuicji dotyczących rzeczywistości? Powszechność tego lekceważenia świadczy o sile i zasięgu owego empirystycznego a priori w nowożytnym myśleniu.

Jak już wspomniałem, to nasze potoczne doświadczenie rzeczy zmysłowych zdaje się stanowić poznawcze źródło naszych spontanicznych mniemań na temat rzeczywistości. Mniemania te wyrażają fakt, iż rzeczy zmysłowych doświadczamy zawsze $\mathrm{w}$ ten sam sposób, mianowicie jako podłoża przysługującego im kształtu, barwy, ciężaru, itd. Arystotelesowskie pojęcie substancji zdaje się stanowić pewne doprecyzowanie takich potocznych mniemań. Wydaje się zatem, iż wykazanie, że tradycyjne pojęcie substancji pochodzi z doświadczenia, powinno się dokonywać poprzez dokładną analizę faktycznego przebiegu naszego potocznego doświadczenia rzeczy zmysłowych. Tak być powinno przy próbie wykazania, iż pojęcie substancji materialnej posiada rzeczywisty charakter poznawczy. Próba wykazania czegoś takiego będzie celem naszych dalszych rozważań. Badanie to będzie zatem przebiegać w opozycji do empirystycznego a priori, na którym opierają się krytyczne analizy Locke'a. Zamiast więc przykrawać doświadczenie do określonych a przyjętych już z góry reguł jego rzetelności, będziemy po prostu badać, jakie reguły dają się wykryć w jego faktycznym przebiegu oraz co owe reguły implikują na temat tak doświadczanej rzeczywistości.

\section{WSTEPNA CHARAKTERYSTYKA NASZEGO POTOCZNEGO DOSWIADCZANIA RZECZY}

Jest rzeczą niewątpliwą, iż w naszym potocznym doświadczaniu rzeczy zmysłowych uczestniczą zwykle akty zmysłowego spostrzegania. Wszak wskazuje się, że zmysł wzroku jest dla człowieka zmysłem poznawczo najważniejszym. Akty zmysłowego spostrzegania są też zazwyczaj najściślej splecione $\mathrm{z}$ całością dokonywanego przez nas spontanicznie potocznego doświadczenia rzeczy i dlatego zapewne tradycyjnie utożsamiano dokonywanie doświadczenia $\mathrm{z}$ dokonywaniem obserwacji. Takie utożsamienie explicite zachodzi $\mathrm{w}$ empirystycznej koncepcji Locke'a.

Aby można było wskazać miejsce aktów zmysłowego spostrzegania w strukturze zmysłowego doświadczenia rzeczy należy najpierw uważniej przyjrzeć się samym tym aktom zmysłowego spostrzegania. 
$\mathrm{Na}$ czym przeto polega każdy taki akt? Otóż akt zmysłowego (tzw. zewnętrznego) spostrzegania czegoś nie polega np. na osobnym ujmowaniu poszczególnych jakości resp. momentów zmysłowych i na pewnego rodzaju konstruowaniu z nich (dopiero) przedmiotu jako pewnej zmysłowej całości. W zmysłowym spostrzeganiu — wskazywał jeszcze Husserl — przedmiot dany jest od razu, w jednym rzucie (in einem Schlage) jako pewna prosta całość zmysłowa ${ }^{19}$. Taką prostą całość zmysłową określa się zazwyczaj jako „wygląd czegoś”. Ukazuje ona bowiem jednostronnie wygląd spostrzeganego przedmiotu, tj. ukazuje nam jaka jest jego przednia względem nas strona. Przedmiot zmysłowy posiada jeszcze swoje inne strony, $\mathrm{np}$. tylną, boczną, wnętrze, itp., lecz pozostają wtedy one dla nas całkowicie lub też częściowo zakryte tym, co ujmujemy naocznie jako jego przednią stronę.

Ponadto zmysłowe spostrzeganie zazwyczaj nie polega na samym tylko zmysłowym percypowaniu ukazującego się nam oto naocznie wyglądu rzeczy. Jest ono raczej zwykle szczególnym „splotem” (ein Gewebe) tego, co właśnie jest nam oto naocznie dane oraz tego, co wówczas jest przez nas zarazem nienaocznie współdomniemane (mitgemeint), tzn. współdomyślone przez nas. Tak np. gdy widzimy wzór na dywanie, który jest częściowo zakryty przez meble: wówczas ta jego część, która jest przez nas aktualnie spostrzegana, jest jakby obarczona intencją, która domniemuje, że linie i kształty barwne „idą dalej” w zakrytej części dywanu na sposób tego, co widzimy w części niezakrytej ${ }^{20}$. Takiego współdomniemaria - wskazywał dalej Husserl - nie należy rozumieć na sposób „oczekiwania” (Erwartung), że nam się jakoś naocznie pokaże zakryta (tu i teraz) część spostrzeganego przedmiotu. Wówczas, gdy tylko statycznie ,gapimy" się na ów przedmiot, oczekiwanie tego byłoby czymś nierozsądnym. Gdyż takie oczekiwanie na ukazanie się nam części dotychczas zakrytej związane jest zazwyczaj z odpowiednim ruchem naszego ciała. To właśnie ten ruch nam obiecuje, że gdy go spełnimy, będziemy dzięki niemu oglądać to, co tu i teraz jest nam jeszcze zakryte ${ }^{21}$.

$\mathrm{W}$ ten sposób w naszym zmysłowym spostrzeganiu rzeczy zachodzi zazwyczaj jakby przekraczanie świadomością (tj. aktami świadomości) tego, co tu i teraz jest nam dane percepcyjnie. Zaś dzięki temu wykraczaniu świadomością ku ukrytym stronom resp. aspektom spostrzeganego przedmiotu, staje się on dla nas czymś, co nas zaciekawia. Zaciekawia nas $\mathrm{w}$ nim właśnie to, jakie są naprawdę te inne, aktualnie dla nas zakryte jego strony. Czy sa one faktycznie takie, jak to sobie np. wyobrażamy? Czy są one rzeczywiście na sposób tego, co tu i teraz jest dla

\footnotetext{
18 E. H u s s e r l,

Logische Untersuchungen, t. II/2, Tübingen 1968, 149

20 Por. tamże, 40 .

21 Por. tamże, 40.
} 
nas jawne jako przednia jego strona? Wzbudza to w nas chęć naocznego przekonania się o tym. Ożywieni tą chęcią spontanicznie - i zazwyczaj bezwiednie - zachowujemy się w określony sposób względem tego, co dotychczas było nam dane naocznie tylko od przedniej strony.

To nasze spontaniczne zachowanie się względem spostrzeganego jednostronnie przedmiotu dokonuje się na sposób określonych ruchów naszego ciała, np. jako odpowiedni ruch naszej ręki, aby sobie coś przybliżyć lub by to odwrócić, przełamać, itp. Niekiedy to odpowiednie zachowanie się ciałem względem spostrzeganego jednostronnie przedmiotu może mieć charakter bardziej całościowy, np. gdy pochylamy się nad czymś, gdy obchodzimy to coś dokoła, itp.

Spełniając spontanicznie tego rodzaju ruchy naszym ciałem względem tego, co wyjściowo (jednostronnie) spostrzegamy, przekonujemy się zazwyczaj jakie są te inne, dotychczas dla nas zakryte strony resp. aspekty tego przedmiotu. Przekonujemy się wówczas zarazem, jakie sposoby zachowania się ciałem (jakie ruchy) są skuteczne, tj. doprowadzają do naocznego ujawnienia się nowych, interesujących nas stron. Widzimy zatem, że nasze ciało słusznie może być nazwane „narzędziem” wszelkiego spostrzegania ${ }^{22}$. Nie wyczerpuje to jednak wszystkich jego funkcji, które spełnia w toku zmysłowego doświadczenia. Stanowi ono bowiem zarazem narzędzie, dzięki któremu możemy bezpośrednio dotrzeć do spostrzeganej rzeczy i sprawić w niej ujmowalne naocznie skutki. Działając ciałem (np. rękoma) na to, co jest nam wyjściowo, jednostronnie dane w aktualnym spostrzeżeniu, zmuszamy jakby to coś, aby nam naocznie ujawniło swoje inne, dotychczas dla nas zakryte aspekty. W ten sposób naocznie przekonujemy się o tym, że one rzeczywiście są oraz, jakie one faktycznie są. Tę funkcję ciała w doświadczaniu aktualnie nam zakrytych stron spostrzeganego przedmiotu, bardzo trafnie uchwycił niegdyś Roman Ingarden ${ }^{23}$.

\section{PROBA OKRESLENIA ISTOTY NASZEGO POTOCZNEGO DOSWIADCZENIA RZECZY ZMYSEOWYCH}

Analizy poprzedniego punktu uwidoczniły nam, że potocznego doświadczenia rzeczy nie da się pojąc jako tylko dokonywania obserwacji, gdyż do takiego doświadczenia przynależą w sposób konstytutywnie konieczny określone zachowania się ciałem przez tego, kto spostrzegając coś, nieuchronnie spostrzega to coś w sposób jednostronny. Zmysłowe spostrzeganie czegoś zdaje się przeto stanowić jedynie jakby punkt wyjś-

22 E. Husserl, Idee czystej fenomenologii $i$ fenomenologicznej filozofii, Kșięga II, tłum. D. Gi e rul a n ka, Kraków 1974, 80.

${ }_{28}$ R. Ingarden, Spór o istnienie świata, t. 2, Warszawa 1961, 84. 
cia (tj. pierwszą fazę) procesu zmysłowego doświadczania czegoś. Nieusuwalna jednostronność każdego aktualnego spostrzegania warunkuje to, iż spostrzegana rzecz posiada swoje, zakryte dla nas aspekty i dlatego może ona dla nas być tym, co tajemnicze i co nas zaciekawia. To zaś zaciekawienie pobudza nas - w sposób spontaniczny, bezwiedny - do określonego zachowania się ciałem względem spostrzeganej jednostronnie rzeczy, tak aby się nam naocznie ujawniły owe interesujące nas, a jeszcze nam nieznane aspekty rzeczy. Zachowując się spontanicznie w określony sposób, np. działając nań rękoma tak a tak, doprowadzamy do zaistnienia w wyglądzie spostrzeganej rzeczy określonych i bezpośrednio ujmowalnych zmian.

Wydaje się, że potoczne doświadczenie rzeczy zmysłowych stanowi szczególny przypadek tych sytuacji, które na co dzień określamy jako doświadczanie kogoś lub czegoś. Celem takiego doświadczania jest naoczne przekonanie się o tym, jaki np. ten ktoś jest naprawdę pod interesującym nas względem. Potocznie mówi się wówczas np., że ktoś pragnie kogoś doświadczyć pod względem wierności, prawdomówności, rzetelności, itp Doświadcza go więc, aby się przekonać, jaki on naprawdę jest pod którymś z tych względów. Analogicznie możemy również mówić o doświadczaniu rozmaitych rzeczy, które napotykamy w potocznym życiu. Napotykając pewną rzecz i pragnąc się przekonać, jaka ta rzecz faktycznie jest pod interesującym mnie względem, np. pod względem smaku, ciężaru, wyglądu odwrotnej strony itp., spontanicznie zachowuję się w określony sposób tak, aby mi się uwidoczniło to, o co mi chodzi.

W życiu potocznym tego rodzaju zachowania doświadczające (kogoś lub czegoś) spełniane są zazwyczaj całkowicie bezwiednie. Udział rozważnego planowania (strategii), co do sposobów najskuteczniejszego zachowania się ciałem, jest tutaj zwykle niewielki. Ta spontaniczna bezwiedność naszego potocznego doświadczania (kogoś lub czegoś) utrzymuje się tak długo, jak długo znajdujemy się w obszarze sytuacji stereotypowych, które są dla nas zrozumiałe - jak mówimy — ,same przez się”. Dopiero wtedy, gdy znajdujemy się wobec czegoś niezwykłego (niezwykłego z punktu widzenia potocznej rutyny), nasze sposoby doświadczającego zachowania się ciałem, tracą - w określonym stopniu - swoją zwykłą spontaniczną bezwiedność na rzecz poszukiwania skutecznego sposobu działania nań, aby się przekonać o.... W sposób szczególnie wyraźny występuje’ to w przemyślanym konstruowaniu eksperymentu naukowego. Nie jest on zatem redukowalny do samego tylko dokonywania obserwacji, wbrew postulatom Locke'owskiej koncepcji doświadczenia.

Te wszystkie uwagi możemy obecnie krótko podsumować, tak aby uwyraźnić istotę procesu poznawczego, zwanego przez nas (niejednokrot- 
nie $\mathrm{z}$ odcieniem lekceważenia) potocznym doświadczeniem rzeczy zmysłowych.

Otóż, jak się wydaje, sytuację wyjściową dla tegoż doświadczenia otwiera nieusuwalna jednostronność każdego zmysłowego spostrzegania czegoś. Lecz właśnie dzięki temu spostrzegana rzecz jest dla nas tajemnicza i budzi nasze zainteresowanie, a to, co z niej aktualnie spostrzegamy, obarczone jest jakby domniemaniami na temat jej innych, zakrytych jeszcze przed nami (tu i teraz) aspektów. Cała ta sytuacja stanowi jakby pierwszą, tj. wstępną, fazę naszego doświadczania rzeczy, która warunkuje możliwość innych kolejnych faz. Drugą fazę doświadczenia zdaje się stanowić spontaniczne podejmowanie przez nas określonych zachowań ciałem (np. rękoma) względem tego, co i jak jest nam wstępnie naocznie dane. Zazwyczaj spontanicznie podejmujemy takie sposoby zachowania się ciałem (np. takie sposoby działania nań...), które dotychczas okazywały się skuteczne. Doprowadza to do zaistnienia trzeciej fazy naszego potocznego doświadczania rzeczy. Faza ta polega na naocznym ujawnianiu się nam określonych, dotychczas nam nieznanych aspektów rzeczy. Bywa, że te ujawniające się nam oto nowe strony, resp. aspekty rzeczy, okazują się zasadniczo odmienne od dotychczas wyobrażanych sobie przez nas. Wiąże się z tym przeżycie zaskoczenia, zdumienia lub rozczarowania. W ten sposób przekonujemy się ostatecznie, jakie faktycznie są te inne, nieznane nam dotychczas aspekty rzeczy. To zaś naoczne przekonanie się o tym stanowi ostatnią (czwartą) fazę procesu doświadczenia a zarazem zasadniczy cel całego tego procesu.

W ten sposób stało się widoczne, że nasze potoczne doświadczenie rzeczy zmysłowych posiada charakter procesu, który rozwija się w kilku kolejnych fazach, ściśle ze sobą powiązanych. Dokonywanie obserwacji występuje na początku oraz na końcu tego procesu. Jednakże to dokonywanie obserwacji posiada inny charakter na początku, inny zaś na końcu procesu doświadczenia. Jest tak dlatego, ponieważ zasadniczo odmienny jest charakter tego co naocznie ujmowane w obu tych skrajnych fazach procesu. To wszystko zdaje się wskazywać, iż Locke'owska koncepcja doświadczenia, przesądzająca a priori, iż każde doświadczenie musi przebiegać jako dokonywanie obserwacji, posiada niewiele wspólnego z faktycznym sposobem dokonywania się doświadczenia.

\section{ANALIZA PRZEBIEGU POTOCZNEGO DOSWIADCZENIA RZECZY I JE. WYNIKI}

Dotychczasowe analizy ukazały nam potoczne doświadczenie rzeczy zmysłowych jako proces istotowo różny od samego tylko dokonywania obserwacji. Analizy te wskazują również, że w faktycznym przebiegu 
takiego doświadczenia dają się wyodrębnić pewne charakterystyczne prawidłowości. Zdają się one być niezwykłe ważne dla naszych poszukiwań poznawczej genezy tradycyjnego pojęcia substancji. Dlatego obecnie przyjrzymy się uważnie, jak przebiega faktyczny proces naszego potozznego doświadczania rzeczy zmysłowych.

Otóż, w miarę jak podejmuję coraz to nowe sposoby zachowania się ciałem (np. działania moimi rękami) względem spostrzeganej rzeczy, ujawniają mi się naocznie coraz to inne, nowe jej aspekty. Mówiąc dokładniej, ujawnia mi się ona w coraz to innych wyglądach spostrzeżeniowych, kTóre w sposób ciągły przechodzą jedne w drugie. Ta ciągłość w zmianach naocznego wyglądu tej samej rzeczy dokonuje się odpowiednio do ciągłości zmian mojego zachowania się ciałem względem niej. Spontaniczne więc uprzytamniam sobie, że sposób modyfikowania się kolejnych wyglądów rzeczy jest ściśle uzależniony od kolejno spełnianych przeze mnie sposobów zachowania się ciałem, np. sposobów bezpośredniego działania nań rękami.

Analizując uważnie tę zależność, uprzytamniam sobie, że:

a) Interesujący mnie aspekt rzeczy będzie mi naocznie ujawniony tylko wówczas, gdy zachowam się w określony, tj. taki a nie inny sposób. Tylko ten sposób zachowania się ciałem będzie wówczas skuteczny. Inne natomiast sposoby zachowania się ciałem (względem tego, co spostrzega) okazują się zawsze, pod tym względem, nieskuteczne.

b) W trakcie wszechstronnego doświadczania ciałem danej rzeczy zmysłowej uprzytomniam sobie, że ta rzecz ukazuje mi się naocznie w pewnej tylko, charakterystycznej dla siebie sekwencji wyglądów. Rownież inne przedmioty, które są potocznie uważane za przedmioty tego samego rodzaju, ujawniają się naocznie $\mathrm{w}$ charakterystycznych a zasadniczo podobnych (analogicznych) sekwencjach wyglądów. Natomiast przedmioty uważane potocznie za przedmioty odmiennych rodzajów, ukazują się $\mathrm{w}$ sekwencjach wyglądów o zasadniczo odmiennym charakterz?.

c) Nie potrafię przewidzieć, jakie nowe wyglądy rzeczy bęłą mi naocznie ukazane, gdy spostrzegając coś całkowicie dla mnie nowegn i nie wiedząc, jak się należy z tym czymś obchodzić, zachowuję się wzg̣?ędem tegoż (np. działam nań rękami) na chybił trafił.

Wszystkie te - wskazane wyżej - prawidłowości zachodzą w trakcie przebiegu mojego potocznego doświadczenia rzeczy w sposób całkowicie niezależny od moich pragnień, wyobrażeń czy oczekiwań. Dlaczego tak właśnie jest? Co decyduje o takim właśnie sposobie dokonywania się naszego potocznego doświadczenia rzeczy zmysłowych?

Otóż tak to wygląda, jak gdyby poza, czy też raczej pod tymi wszystkimi poszczególnymi wyglądami rzeczy, które mi się kolejno naocznie 
ujawniają w toku doświadczenia, tkwiło jeszcze coś, co jako autonomiczna zasada decyduje o tym:

- w jaki sposób będzie przebiegać sekwencja wyglądów rzeczy odpowiednio do spełnianych przeze mnie sposobów zachowania się ciałem,

- jaki wygląd zostanie mi naocznie ujawniony, gdy spełnię określone, tj. takie a nie inne zachowanie się ciałem względem tej spostrzeganej zawsze jednostronnie rzeczy,

- jakie sposoby zachowania się ciałem są wtedy w ogóle skuteczne, tj. prowadzą do naocznego ujawnienia się interesującego mnie aspektu rzeczy, np. jej wnętrza, tylnej strony, itp.,

- jakie sposoby zachowania się ciałem są pod tym względem nieskuteczne, daremne,

- jakiego rodzaju wyglądy naoczne są dla danej rzeczy charakterystyczne. Rzecz ukazuje mi się bowiem zawsze w określonych, tylko takich, a nie innych naocznych wyglądach.

Należy tutaj jeszcze dodać, że sama ta autonomiczna zasada, która rządzi faktycznym przebiegiem naszego potocznego doświadczenia rzeczy, nie jest już czymś co dałoby się ując spostrzeżeniowo. Jest ona jedynie intelektualnie uprzytamniana na gruncie analizy przebiegu naszego potocznego doświadczenia.

\section{POTWIERDZENIE ARYSTOTELESOWEJ INTUICJI DOTYCZĄCEJ SUBSTANCJI MATERIALNEJ}

Rozważania poprzedniego punktu starały się pokazać, w jaki sposób na gruncie analizy przebiegu naszego potocznego doświadczania rzeczy zmysłowych uprzytomniamy sobie coś, co tkwi jakby pod wszelkimi spostrzeganymi przez nas naocznymi wyglądami rzeczy. To coś nie tylko decyduje o faktycznym przebiegu naszego doświadczenia, lecz również jakby wyznacza, jakie w ogóle wyglądy naoczne przysługują tej rzeczy jako jej własne, tj. w jakich wyglądach może się nam ona w ogóle naocznie pokazać. Czymże przeto jest samo to coś?

Otóż to coś zdaje się stanowić za każdym razem pewną jednostkową rzecz, która uobecnia się nam naocznie (przejawia) poprzez określone charakterystyczne dla niej — jednostronne wyglądy. Wyglady te przysługują owej jednostkowej rzeczy, przynależą do niej właśnie jako charakterystyczne dla jej sposobu naocznego przejawiania się. Można powiedzieć, że są one przez tę rzecz posiadane i nie utożsamiają się z nią samą. Treściowa zawartość każdego z tych charakterystycznych wyglądów rzeczy może zostać na drodze prostej abstrakcji rozłożona na poszcze- 
gólne momenty zmysłowe, tj. na tzw. cechy zmysłowe. Są to takie np. cechy, które określamy potocznie jako „kształt”, „,barwa”, „gładkość”, „połysk metaliczny”, „twardość”, itp.

Owe cechy, czy też własności, w ten sam sposób przynależą do samej rzeczy, jak do niej przynależą ukonstytuowane z nich całościowe wyglądy naoczne. W życiu potocznym uprzytamniamy sobie spontanicznie, że tak właśnie jest i dajemy temu wyraz w codziennym odnoszeniu się do rzeczy zmysłowych i w wypowiadaniu się o nich. Wszak żyjąc potocznie, ustawicznie traktujemy wszelkie rzeczy zmysłowe jako posiadające rozmaite spostrzegalne własności. Traktujemy je zatem jako bytowe podłoże tych własności, które same są bytowo niesamodzielne, tzn. nie mogłyby w ogóle istnieć bez takiego bytowego podłoża.

A zatem to coś, które zostało przez nas wyanalizowane na podstawie faktycznego przebiegu potocznego doświadczenia rzeczy, zdaje się w pełni odpowiadać podanej przez Arystotelesa charakterystyce substancji. W jego Metafizyce czytamy np.: „Wydaje się przeto, iż rzeczom (...) przysługuje byt $\mathrm{w}$ najwyższym stopniu, jako że posiadają pewien określony substrat. A substrat ten jest substancją i rzeczą jednostkową, co się ujawnia przy orzekaniu o nim różnych własności" ${ }^{24}$.

Nasze analizy dotyczące przebiegu potocznego doświadczenia rzeczy zmysłowych zdają się faktycznie wskazywać, iż to, co tkwi jakoś pod wszelkimi poszczególnymi wyglądami rzeczy i decyduje o sposobie przebiegania każdorazowego doświadczenia, stanowi pewną jednostkową rzecz. Ujawnia się nam ona naocznie w określonych, charakterystycznych dla siebie wyglądach i tylko w nich może się nam ona w ogóle pokazywać. Ta rzecz jednostkowa, posiadając owe charakterystyczne dla siebie wyglądy, stanowi ich bytowe podłoże i nie może być zredukowana do sumy tych swoich własności (cech zmysłowych), gdyż jej bytowy charakter jest zupełnie inny.

Wszystko to zdaje się przeto wskazywać, iż rzeczywiście na drodze analizy przebiegu naszego potocznego doświadczenia rzeczy zmysłowych, możliwe jest wskazanie poznawczego źródła dla tradycyjnego metafizycznego pojęcia substancji materialnej.

${ }^{24}$ Arystoteles, jw., 158 


\section{DAS PROBLEM DES MÖGLICHEN ERKENNENS DER SOGENANNTEN} SUBSTANZ

\section{$\mathbf{Z}$ u s m m e n f a s u n $\mathrm{g}$}

Die vorliegende Betrachtung versucht den Nachweis zu erbringen, dass der traditionelle Begriff der Substanz der Erfahrung entstammt. Es ist aber nicht eine im Sinne der Forderungen J. Lockes empiristich gefasste Erfahrung, sondern eine ganz gewöhnliche Umgangserfahrung der Sachen, die unbewusst und immer wieder im Laufe unserer alltäglichen Lebensaktivität zutrifft.

In dieser gewöhnlichen Erfahrung der sinnlichen Sachen spielt immer eine grundlegende Rolle die jeweilige Körpertätigkeit des Wahrnehmenden gegenüber den wahrgenommenen Sachen, um sich von etwas zu vergewissern, z.B. vom augenscheinlichen Aussehen der ,entgegengesetzten Seite" der wahrgenommenen Sache. Die Untersuchung des Ablaufes einer alltäglichen Erfahrung enthült bestimmte Regelmässigkeiten, die jedesmal in diesem Ablauf stattfinden.

Es erweist sich, dass die Ablaufsart der Erfahrung von der "Sache selbst" determiniert ist, dass die "Sache selbst” darüber entscheidet, welches augenscheinliche „Aussehen” und welche wahrnehmbare, für die Sache charakterisitische Zeichen sie uns in der Erscheinung zeigen kann. Diese „Sache selbst”, die über den tatsächlichen Ablauf der gewöhnlichen Erfahrung entscheidet, entschleiert sich als wesentlich übereinstimmend mit der aristotelischen Auffassung der Sache als "Substanz". 